\title{
Comparative Study between the Effect of Melatonin and Hyaluronic acid on Induced Bone Defect Healing in Rabbit
}

\author{
Rawaa Abdul-Jabbar Mahmood ${ }^{\mathbf{1}}$, Noor Abdulkareem Razouki \\ ${ }^{1}$ Assist. Lecturer, B.D.S., M.Sc. Al-Rafidain University College, Iraq; \\ ${ }^{2}$ Assist. Lecturer, B.D.S., H.D.D., M.Sc., Al-Rafidain University College, Iraq
}

\begin{abstract}
This study was aimed to highlight the individual effects of melatonin (MEL) and hyaluronic acid (HA) on bone healing and repair mechanism and to investigate a possible effect, for a topical application. New Zealand rabbits used in this study were divided into three groups for two healing intervals the experimental groups were: 1. Experimental groups (20 rabbits): all animals subjected to surgical operation in right tibia, creating bone defect $3 \mathrm{~mm}$ in depth and $4 \mathrm{~mm}$ in diameter filled with $0.1 \mathrm{ml}$. Hyaluronic acid gel and left tibia bone defect filled with melatonin gel. 2. Control group (10 rabbits): induced bone defect on the right side only. Animals' scarifications were done in 2 weeks and 4 weeks' durations. Routine processing and sectioning technique was performed for histological evaluation. At the 2 weeks healing interval, highest mean value of all measured parameters were recorded at melatonin group while at 4 weeks, there is high significant difference in all parameters; ( $p$-value 0.000) among all control and experimental groups. A significant number of positive effects of MEL, as well as HA, as individual compounds on the bone healing regeneration.
\end{abstract}

Keywords: Melatonin, Hyaluronic acid, Bone, Rabbit

\section{Introduction}

Biomaterials have different groups but we focus here on the naturally derived types that present already in the body from natural origin like melatonin and hyaluronic acid ${ }^{1}$. It should be stable, biocompatible; ideally osseoinductive and conductive, porous and similar to biological bone mechanically ${ }^{2}$ Melatonin is discovered and isolated by Lerner in 1958, is a natural hormone produced mainly by the pineal gland but also by other tissues and organs, such as the retina, brain, bone marrow, Harderian gland, ciliary body, lens, thymus, airway epithelium, gonads, placenta, gastrointestinal tract and skin, in a circadian manner, with the highest level during the night (between midnight and 2 a.m. for healthy adults) and a minimum during the day. ${ }^{3,4}$

It act as a radical scavenger antioxidant ( $\mathrm{N}$-acetyl5-methoxytryptamine) which has the ability to stimulate antioxidant enzymes that neutralize free radicals and ROS. Melatonin also contributes to the maintenance of bone health by promoting osteoblast differentiation and limiting osteoclastic activity. Bone healing process consists of inflammatory, proliferative, and remodeling phase. The production of free radicles causes cell damage and distribution of bone healing process due to the production of free radicals causes cell damage and disruption of bone healing process due to the chain reactions of protein and lipid peroxidation. Melatonin participates in the physiological functions of bone cells, promotes angiogenesis and, through its free radical scavenging properties, it may also serve as a preventive agent against radical-induced hard tissue damages 5

Hyaluronic acid (HA) is a naturally-derived polymers biomaterial. It is a major component of the extra cellular matrix (ECM) and present in nearly every mammalian tissue and fluid. It plays a role in wound healing and it has been found in high concentrations in the early fracture callus, in lacunae surrounding hypertrophic chondrocyte in the growth plate and in the cytoplasm of osteoprogenitor cells ${ }^{6}$. (HA) has osteoconductive potential; it accelerates the bone regeneration by means of chemotaxis, proliferation and 
successive differentiation of mesenchymal cells. HA may act as biomaterial scaffold for other molecules, such as BMP-2 and TGF- $\beta$, used in guided bone regeneration techniques and tissue engineering research. ${ }^{7}$.

\section{Materials and Method}

The materials used in the present study were hyaluronic acid gel, melatonin (5mg, USA), anesthetic solution: Ketamine hydrochloride $50 \mathrm{mg}$ and Xylazine $2 \%$, formalin $10 \%$, ethanol alcohol $96 \%$, xylol, paraffin wax, and Hematoxylin and Eosin (H\&E) stain.

Thirty male New Zealand rabbits weighting (1.5$2 \mathrm{~kg}$ ), aged (6-12) months used in this study; they were divided into control group (10 rabbits) and experimental group (20 rabbits) tibial induced bone defect(with $3 \mathrm{~mm}$ an diameter and $4 \mathrm{~mm}$ depth) into right tibia filled with $0.1 \mathrm{ml}$ Hyaluronic acid gel and left tibia bone defect that filled with melatonin gel $(5 \mathrm{mg})$. While the control group induced bone defect in right side only. Rabbits are sacrificed by an overdose of anesthetic solution at two healing intervals 2 weeks, 4 weeks fifteen on each period. All tissue specimens, experimental and controls were fixed in $10 \%$ neutral formalin Animals were scarified and processed in routine paraffin blocks after complete decalcification of bone. Histological evaluation was performed using light microscope (OpticaB-350, Italy). Histomorphomatrical parameters are measure the number of bone cells (osteoblasts, osteocyte, and osteoclasts), trabecular area $\left(\mathrm{mm}^{2}\right)$, bone marrow area $\left(\mathrm{mm}^{2}\right)$ and trabecular number. Measurements were performed by image processing software program

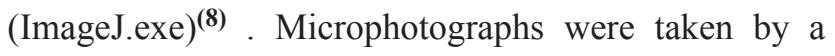
camera (AIPTEK HD 1080P, China) attached to the microscope at power X40.

\section{Statistical analyses}

Data were analyzed using SPSS (statistical package of social science) software version 25 . In this study the following statistics were used:

1. Descriptive statistics: including means, standard deviations and statistical tables and figures.

2. Inferential statistics: including:

a) One-way ANOVA test: to compare the measured variables among the groups.

b) Tukey's HSD test: to test any statistically significant difference between each two groups.

c) Independent sample t-test: to test the effect of time on the measured parameters.

\section{Cl. 27(1), March 2015 Evaluation the effect}

\section{Results}

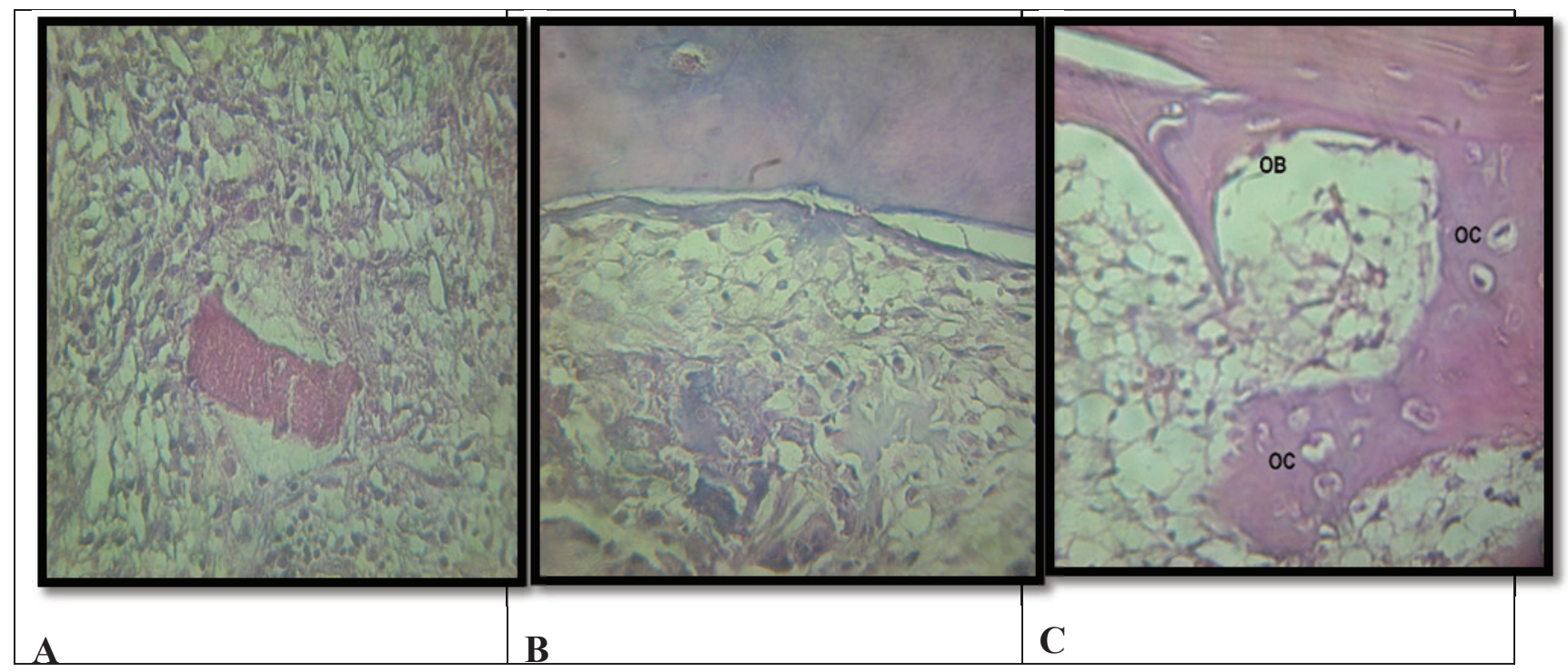

Figure (1): Microphotograph view of defect area of 2 weeks healing period shows in: (A) Control group blood clot surrounded by inflammatory cells and bone marrow stromal cells (100X) .(B) Hyaluronic acid group: shows flecks of bone trabeculae and osteoid tissues rimed by few osteoblast(100X). (C) Melatonin group shows bone marrow surrounded by bone trabeculae with osteocyte (OC) inside and osteoblast $(\mathrm{OB})$ at periphery $(400 \mathrm{X})$. 


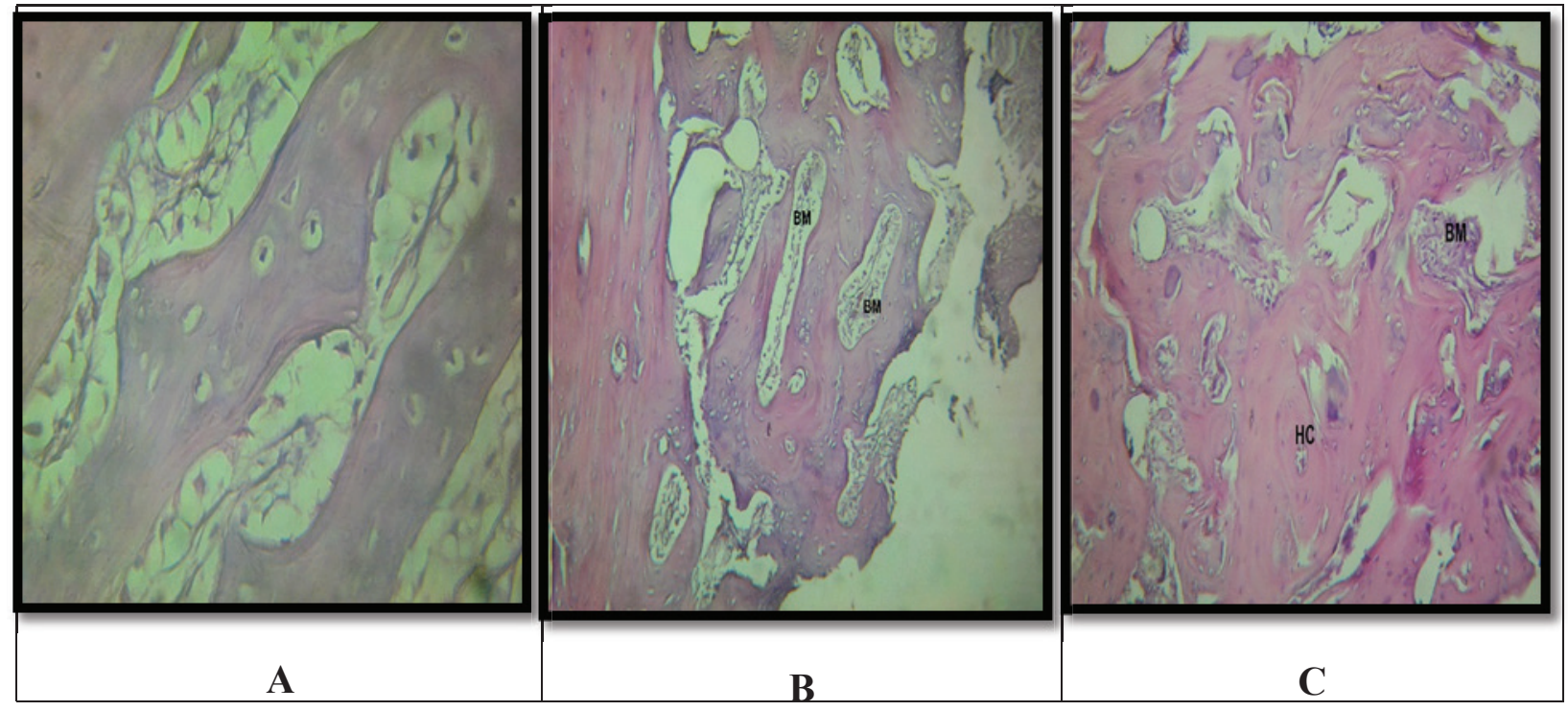

Figure (2): Microphotograph view of defect area of 4 weeks healing period shows in: (A) Control group new bone trabeculae enclosing bone marrow (400X). (B) Hyaluronic acid group shows compacted bone trabeculae enclosing less bone marrow area (100X). (C) Melatonin group shows defect site filled with new bone (NB) enclosing marrow tissue (MT) (100X). Use Magnified views

\section{Histomorphometrical analysis of bone architecture parameters:}

All measured parameters showed increased mean values with time, except for bone marrow area mean values decreased in all groups. At 2 weeks healing interval, highest mean values of all measured parameters were recorded at melatonin group however bone marrow area showed highest values in control group (Table 1). The melatonin and HA groups show a high significant differences in all bone histomorphometrical parameters compared with control group except osteocytes count non significance difference was recorded between control and HA groups(Table 2).

Table 1: Descriptive statistics and group difference in 2 weeks

\begin{tabular}{|c|c|c|c|c|c|c|}
\hline \multirow{2}{*}{ Parameters } & \multirow{2}{*}{ Groups } & \multicolumn{3}{|c|}{ Descriptive statistics } & \multicolumn{2}{|c|}{ Group difference } \\
\hline & & $\mathbf{N}$ & Mean & S.D. & F-test & p-value \\
\hline \multirow{3}{*}{$\begin{array}{l}\text { Trabecular } \\
\text { Numbers }\end{array}$} & Control & 5 & 2.220 & 0.148 & \multirow{3}{*}{77.998} & \multirow{3}{*}{0.000} \\
\hline & Melatonin & 10 & 5.810 & 0.801 & & \\
\hline & HA & 10 & 4 & 0.240 & & \\
\hline \multirow{3}{*}{ Osteocytes } & Control & 5 & 5.800 & 0.837 & \multirow{3}{*}{1246.705} & \multirow{3}{*}{0.000} \\
\hline & Melatonin & 10 & 23.680 & 1.220 & & \\
\hline & HA & 10 & 6.030 & 0.221 & & \\
\hline \multirow{3}{*}{ Osteoblasts } & Control & 5 & 5.300 & 1.204 & \multirow{3}{*}{383.955} & \multirow{3}{*}{0.000} \\
\hline & Melatonin & 10 & 24.160 & 2.051 & & \\
\hline & HA & 10 & 10 & 0.330 & & \\
\hline \multirow{3}{*}{$\begin{array}{l}\text { Bone } \\
\text { Marrow } \\
\text { Area }\end{array}$} & Control & 5 & 0.490 & 0.026 & \multirow{3}{*}{279.469} & \multirow{3}{*}{0.000} \\
\hline & Melatonin & 10 & 0.212 & 0.020 & & \\
\hline & HA & 10 & 0.410 & 0.026 & & \\
\hline \multirow{3}{*}{$\begin{array}{l}\text { Trabecular } \\
\text { Area }\end{array}$} & Control & 5 & 0.098 & 0.015 & \multirow{3}{*}{744.314} & \multirow{3}{*}{0.000} \\
\hline & Melatonin & 10 & 0.462 & 0.025 & & \\
\hline & HA & 10 & 0.153 & 0.018 & & \\
\hline
\end{tabular}


Table 2: Post hoc Tukey's HSD test for multiple comparisons at 2weeks healing interval

\begin{tabular}{|c|c|c|c|c|}
\hline Parameters & \multicolumn{2}{|l|}{ Groups } & Mean Difference & p-value \\
\hline \multirow{3}{*}{$\begin{array}{l}\text { Trabecular } \\
\text { Numbers }\end{array}$} & \multirow{2}{*}{ Control } & Melatonin & -3.590 & 0.000 \\
\hline & & HA & -1.780 & 0.000 \\
\hline & Melatonin & HA & 1.810 & 0.000 \\
\hline \multirow{3}{*}{ Osteocytes } & \multirow{2}{*}{ Control } & Melatonin & -17.880 & 0.000 \\
\hline & & HA & -0.230 & 0.880 \\
\hline & Melatonin & HA & 17.650 & 0.000 \\
\hline \multirow{3}{*}{ Osteoblasts } & \multirow{2}{*}{ Control } & Melatonin & -18.860 & 0.000 \\
\hline & & HA & -4.700 & 0.000 \\
\hline & Melatonin & HA & 14.160 & 0.000 \\
\hline \multirow{3}{*}{$\begin{array}{l}\text { Bone } \\
\text { Marrow } \\
\text { Area }\end{array}$} & \multirow{2}{*}{ Control } & Melatonin & 0.278 & 0.000 \\
\hline & & HA & 0.080 & 0.000 \\
\hline & Melatonin & HA & -0.198 & 0.000 \\
\hline \multirow{3}{*}{$\begin{array}{l}\text { Trabecular } \\
\text { Area }\end{array}$} & \multirow{2}{*}{ Control } & Melatonin & -0.364 & 0.000 \\
\hline & & HA & -0.055 & 0.000 \\
\hline & Melatonin & HA & 0.309 & 0.000 \\
\hline
\end{tabular}

At 4 weeks of induced bone defect healing period, there were high significant differences (p-value 0.000) among all control and experimental groups (Table 3). The melatonin group revealed highest mean value in all parameters except bone marrow area and osteoblasts which recorded high significant differences (p-value 0.000) at control group and HA group respectively (Table 4).

Table 3: Descriptive statistics and group difference in 4 weeks

\begin{tabular}{|c|c|c|c|c|c|c|}
\hline \multirow{2}{*}{ Parameters } & \multirow{2}{*}{ Groups } & \multicolumn{3}{|c|}{ Descriptive statistics } & \multicolumn{2}{|c|}{ Group difference } \\
\hline & & $\mathbf{N}$ & Mean & S.D. & F-test & p-value \\
\hline \multirow{3}{*}{$\begin{array}{l}\text { Trabecular } \\
\text { Numbers }\end{array}$} & Control & 5 & 3.540 & 0.456 & \multirow{3}{*}{98.179} & \multirow{3}{*}{0.000} \\
\hline & Melatonin & 10 & 10.630 & 1.361 & & \\
\hline & HA & 10 & 4.900 & 0.994 & & \\
\hline \multirow{3}{*}{ Osteoclasts } & Control & 5 & 10.180 & 1.327 & \multirow{3}{*}{714.458} & \multirow{3}{*}{0.000} \\
\hline & Melatonin & 10 & 34.230 & 1.572 & & \\
\hline & HA & 10 & 15.200 & 1.135 & & \\
\hline \multirow{3}{*}{ Osteoblasts } & Control & 5 & 9.440 & 0.918 & \multirow{3}{*}{194.704} & \multirow{3}{*}{0.000} \\
\hline & Melatonin & 10 & 25.210 & 1.602 & & \\
\hline & HA & 10 & 26.200 & 1.932 & & \\
\hline \multirow{3}{*}{$\begin{array}{l}\text { Bone } \\
\text { Marrow } \\
\text { Area }\end{array}$} & Control & 5 & 0.394 & 0.038 & \multirow{3}{*}{303.360} & \multirow{3}{*}{0.000} \\
\hline & Melatonin & 10 & 0.108 & 0.017 & & \\
\hline & HA & 10 & 0.230 & 0.013 & & \\
\hline \multirow{3}{*}{$\begin{array}{l}\text { Trabecular } \\
\text { Area }\end{array}$} & Control & 5 & 0.120 & 0.012 & \multirow{3}{*}{244.232} & \multirow{3}{*}{0.000} \\
\hline & Melatonin & 10 & 0.569 & 0.041 & & \\
\hline & HA & 10 & 0.410 & 0.040 & & \\
\hline
\end{tabular}


Table 4: Post hoc Tukey's HSD test for multiple comparisons

\begin{tabular}{|c|c|c|c|c|}
\hline Parameters & \multicolumn{2}{|l|}{ Groups } & Mean Difference & p-value \\
\hline \multirow{3}{*}{$\begin{array}{l}\text { Trabecular } \\
\text { Numbers }\end{array}$} & \multirow{2}{*}{ Control } & Melatonin & -7.090 & 0.000 \\
\hline & & HA & -1.360 & 0.082 \\
\hline & Melatonin & HA & 5.730 & 0.000 \\
\hline \multirow{3}{*}{ Osteoclasts } & \multirow{2}{*}{ Control } & Melatonin & -24.050 & 0.000 \\
\hline & & HA & -5.020 & 0.000 \\
\hline & Melatonin & HA & 19.030 & 0.000 \\
\hline \multirow{3}{*}{ Osteoblasts } & \multirow{2}{*}{ Control } & Melatonin & -15.770 & 0.000 \\
\hline & & HA & -16.760 & 0.000 \\
\hline & Melatonin & HA & -0.990 & 0.389 \\
\hline \multirow{3}{*}{$\begin{array}{l}\text { Bone } \\
\text { Marrow } \\
\text { Area }\end{array}$} & \multirow{2}{*}{ Control } & Melatonin & 0.286 & 0.000 \\
\hline & & HA & 0.164 & 0.000 \\
\hline & Melatonin & HA & -0.122 & 0.000 \\
\hline \multirow{3}{*}{$\begin{array}{l}\text { Trabecular } \\
\text { Area }\end{array}$} & \multirow{2}{*}{ Control } & Melatonin & -0.449 & 0.000 \\
\hline & & HA & -0.290 & 0.000 \\
\hline & Melatonin & HA & 0.159 & 0.000 \\
\hline
\end{tabular}

\section{Discussion}

This study was aimed to highlight the individual effects of (MEL) and (HA) on bone healing and repair mechanism and to investigate a possible effect, for a topical application.

Thus, it seems that local administration of melatonin during bone fracture could directly stimulate osteoblasts from the endosteum. This was in agreement with the findings shown by Nakade et al ${ }^{9}$

Melatonin has been recently reported to stimulate osteoblasts proliferation and differentiation $(\mathbf{9 , 1 0 )}$.

These results were also in agreement with those of Cutando et al ${ }^{11}$

Finally, (MEL) acts as stabilize cell membranes, thereby making them more resistant to oxidative attacks. $12-15$.
HA enhances the bone healing regeneration 16 While Aslan etal ${ }^{17}$ revealed that HA stimulate bone healing through accelerating the three phases of healing; inflammation, proliferation and migration of mesenchymal cells and they confirmed that HA needs an osteoconductive scaffold to be effective, Other study illustrated that the HA was osteoconductive material that enhance osteogenesis and accelerated bone healing process by promoting cell adhesion and osteoblast differentiation. ${ }^{18}$

\section{Conclusions}

A significant number of positive effects of MEL, as well as HA, as individual compounds on the bone healing regeneration.

Financial Disclosure: There is no financial disclosure.

Conflict of Interest: None to declare. 
Ethical Clearance: All experimental protocols were approved and all experiments were carried out in accordance with approved guidelines.

\section{References}

1. Li RH, Wozney JM. Delivering on the promise of bone morphogenetic proteins. Trends in biotechnology. 2001;19(7):255-65.

2. Salma I, Pilmane M, Skagers A, Vetra J, Salms G, Berzina-Cimdina L, et al. Early morphofunctional response of contact tissue after intraosalimplantation in rabbit jaw of pure synthetic hydroxyapatite (HAp) bioceramic materials and HAp saturated with lidocaine. Stomatologija. 2009;11(4):113-8.

3. Chowdhury I, Sengupta A, Maitra SK. Melatonin: fifty years of scientific journey from the discovery in bovine pineal gland to delineation of functions in human. 2008.

4. Cristache CM, Totu EE, Cristache G, Nechifor AC, Pintilie II. Melatonin and Hyaluronic Acid in Periodontal Disease. REVISTA DE CHIMIE. 2019;70(3):1089-93.

5. Claustrat B, Brun J, Chazot G. The basic physiology and pathophysiology of melatonin. Sleep medicine reviews. 2005;9(1):11-24.

6. Leach JB, Bivens KA, Collins CN, Schmidt CE. Development of photocrosslinkable hyaluronic acid $\square$ polyethylene $\quad$ glycol $\square$ peptide composite hydrogels for soft tissue engineering. Journal of Biomedical Materials Research Part A: An Official Journal of The Society for Biomaterials, The Japanese Society for Biomaterials, and The Australian Society for Biomaterials and the Korean Society for Biomaterials. 2004;70(1):74-82.

7. Bansal J, Kedige SD, Anand S. Hyaluronic acid: A promising mediator for periodontal regeneration. Indian journal of dental research. 2010;21(4):575.

8. Razouki NA, Ghani BA. Histological Evaluation of Effect of beta-Tricalcium Phosphate on Bone healing in Alloxan-Induced diabetes. Journal of Baghdad College of Dentistry. 2016;325(3765):17.

9. Nakade O, Koyama H, Ariji H, Yajima A, Kaku T. Melatonin stimulates proliferation and type I collagen synthesis in human bone cells in vitro. Journal of pineal research. 1999;27(2):106-10.

10. Roth JA, Kim B-G, Lin W-L, Cho M-I. Melatonin promotes osteoblast differentiation and bone formation. Journal of Biological Chemistry. 1999;274(31):22041-7.

11. Cutando A, Gómez $\square$ Moreno G, Arana C, Muñoz F, Lopez $\square$ Peña M, Stephenson J, et al. Melatonin stimulates osteointegration of dental implants. Journal of Pineal Research. 2008;45(2):174-9.

12. Reiter RJ, Tan D-x, Osuna C, Gitto E. Actions of melatonin in the reduction of oxidative stress. Journal of biomedical science. 2000;7(6):444-58.

13. Reiter R, Tang L, Garcia JJ, Muñoz-Hoyos A. Pharmacological actions of melatonin in oxygen radical pathophysiology. Life sciences. 1997;60(25):2255-71.

14. Nkenke E, Kloss F, Wiltfang J, Schultze $\square$ Mosgau S, Radespiel $\square$ Tröger M, Loos K, et al. Histomorphometric and fluorescence microscopic analysis of bone remodelling after installation of implants using an osteotome technique. Clinical oral implants research. 2002;13(6):595-602.

15. Takechi M, Tatehara S, Satomura K, Fujisawa K, Nagayama M. Effect of FGF-2 and melatonin on implant bone healing: a histomorphometric study. Journal of Materials Science: Materials in Medicine. 2008;19(8):2949-52.

16. Ahmad Al Nashar IA, Yasser Khedder and Osama Al-Khatib. EVALUATION THE EFFECT OF HYALURONIC ACID ON BONE HEALING PROCESS: AN EXPERIMENTAL STUDY IN THE RABBITS. EUROPEAN JOURNAL OF PHARMACEUTICAL AND MEDICAL RESEARCH. 2017;,4((1)): 98-101.

17. Aslan M, Şimşek G, Dayi E. The effect of hyaluronic acid-supplemented bone graft in bone healing: experimental study in rabbits. Journal of biomaterials applications. 2006;20(3):209-20.

18. Radhi IH, Al-Ghaban NM. Evaluation the effect of hyaluronic acid on bone healing process in rabbits (Immunohistochemical study for TGF- $\beta$ ). Journal of Baghdad College of Dentistry. 2015;325(2218):113. 